\title{
What's in a latin name?: Cycas wadei \& the politics of nomenclature
}

\author{
Kathleen Cruz Gutierrez ${ }^{*}$
}

\begin{abstract}
This history piece analyzes colonial-era correspondence and botany publications fascinated with Cycas wadei, a cycad observed only to grow on the island of Culion in the province of Palawan. First spotted in 1902 by U.S. botanist Elmer D. Merrill, the cycad became the preoccupation of U.S. and Filipino scientists alike. It took nearly three and a half decades before the species was introduced in the Philippine Journal of Science in 1936 as $C$. wadei, named after Herbert W. Wade, head physician of the Culion leper colony established by the U.S. colonial government at the turn of the century. Tracking the history of this species-from its first sighting to its debut before the international botany community — reveals much about the institutional workings of colonial science in the Philippines in the years leading up to the Commonwealth era. It further inspires us to take stock of the ways in which the politics of Latin binomial nomenclature of a species can be historicized across scales of human and institutional interaction. Such an intellectual practice can help us continue to shed light on the history of taxonomy in the Philippines.
\end{abstract}

KEYWORDS: cycads, taxonomy, Philippine history, Bureau of Science, U.S. colonialism

\section{INTRODUCTION}

In 1931, U.S. botanist Elmer D. Merrill wrote to his colleague about the existence of a unique species of cycad collected on Culion Island in the province of Palawan. Merrill wrote, "Among the plants sent in for identification from Culion is a very excellent fruiting specimen of the Cycas with narrow leaflets of which I collected sterile specimens in 1902; this is undoubtedly an undescribed species, and I have tentatively named it Cycas herrel' (E.D. Merrill to W.H. Brown, August 10, 1931). The plant's characteristics distinguished it from other cycads collected previously. According to Merrill, the species had been first observed while on a "single day's trip" to "a large open grassy area locally known as the cogonal grande or the patag grande originally selected as a possible site for the Culion leper colony [f. 1902]" (Merrill 1936, 233). Merrill deemed the cycad "a curious species" after comparing

Department of South \& Southeast Asian Studies, University of California, Berkeley

International Studies Department, De La Salle University, Manila

*Corresponding email: gutierrezk@berkeley.edu

Date Submitted: 14 September 2018

Date Accepted: 10 January 2019 his scant material with similar specimens held at the Kew Herbarium (Merrill 1922, 1).

After notifying his colleague in 1931 of what seemed to be a new species, Merrill and his Philippines-based associates scrutinized the plant and distinguished it from earlier erroneous identifications (Merrill 1936, 235). In 1936, the cycad was introduced to the international botany community in the Philippine Journal of Science. Though Merrill had originally recommended it be named in honor of Albert W.C.T. Herre, ichthyologist with the Philippine Bureau of Science, the species was named Cycas wadei after Herbert W. Wade, pathologist and physician at the leper colony from 1922 until his death in 1968.

\section{Charting a Plant's Colonial Intellectual History}

The distinction between Cycas herrei and Cycas wadei is not an arbitrary one. The different names carry a dense narrative that weaves the history of science in the Philippines, colonial politics, and the continued land use of bio-diverse regions of the Philippines. The documentation of the first sighting of the curious cycad up through its debut to international botanical taxonomy sheds light on the nuances of colonial intellectual history in the Philippines. This kind of colonial intellectual history, specifically told 


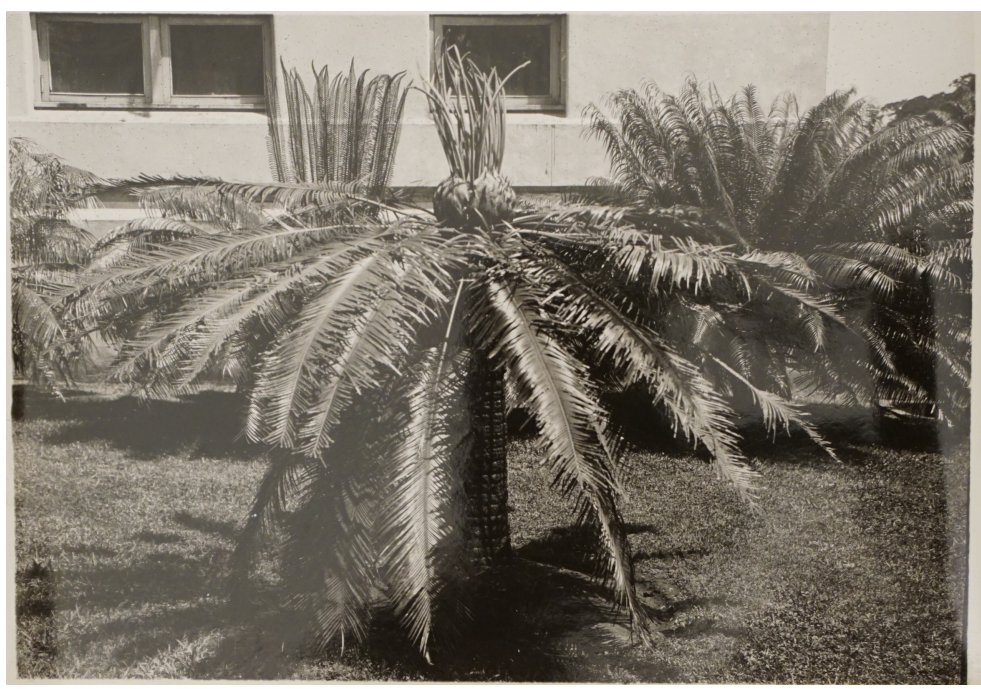

Figure 1. Image of live female $C$. wadei specimen on Bureau of Science grounds, Manila. Elmer D. Merrill Papers [hereafter EDMP], Series 3 (Oversized), Archives of The New York Botanical Garden.

through $C$. wadei, gives us the chance to use the species as an optic through which to understand the workings of colonial science in the Philippines and the politics of taxonomy in the early twentieth century.

Historically tracking single plant species is not novel. Christine Folch's diachronic study of the market for and meaning of yerba mate (Ilex paraguariensis) shows how a plant's commodity value-materially, socially, and internationallyhas changed from that of royal tribute for Spanish imperial subjects to a new age product for a "global cosmopolitan class concerned with quality and authenticity" (Folch 2010, 30). Yerba mate's travels across modern financial circuits, as Folch shows, motivates commentary on empires, trade, and the shifting co-constructed meanings between a plant and its consumers. Timothy P. Barnard's work on the Rafflesia caught in the "discourse of imperial control and classification originating in the laboratories and botanical gardens of Europe" vividly demonstrates how a genus can contribute to the scientific imagination of island Southeast Asia (Barnard 2015). These studies complement the vast literature that has investigated the intellectual, political, and commercial significance of the Oryza (Carney 2001; 2002), Nicotiana (De Jesus 1998), Strophanthus (Osseo-Asare 2014), and Panax (Appleby 1983; Parsons 2016) genera.

I deploy this method to shed light on Philippine history, U.S. colonial science, and the politics of Latin nomenclature. The center of this story is not a plant with heavily purported commercial or medicinal value, but instead an ornamental cycad known commonly in Tagalog as pitogo or in English as Wade's pitogo. Pitogo can broadly refer to a number of Cycas species that grow endemically on particular islands in the Philippines. For the Palawano language, Nicole Revel (1990,
191) lists pitogo as the local name for $C$. rumphii, though a more contemporary revision of the Cycas genera reports that C. rumphii does not occur in the Philippines (De Laubenfels \& Adema $1998^{2}$ ). Commonly, leaves of pitogo species are used as palm branches for ceremonial Holy Week activities, and seeds go into the manufacture of crafts, toys, and decorative ephemera (Agoo et al. 2018, 530). As intellectual history is broadly defined as the history of ideas and thinkers, I am interested in how early twentieth-century colonial scientists were enamored with the idea of $C$. wade - that is the idea of its being a new species, worthy of a unique description and a different name. Though surely a rich history of pitogo existed in the Philippines prior to the start of the U.S. colonial period in 1898, I follow the scientists who first spotted this specific cycad in 1902 up through the publication of the plant's description in 1936.

While the work of taxonomists requires historical sensitivity to annotate material responsibly (Daston 2012), this paper directs historical sensitivity toward how a plant's Latin name came to be. I seek not to take for granted processes of Latin naming that make a species legible to an international botany community. Through this type of history, scholars choose to confront several problems: that of "official discovery," of naming and taxonomy, and of the direct confrontations_or lack thereof-that occurred in the location of a plant's discovery. While these issues may be less murky for a trained biological taxonomist, for historians of science institutional politics, intellectual attachments, and personal ambitions may factor significantly into decisions behind a plant's Latin name. For a prolific botanist like Merrill, whose publication record includes the description of dozens of Philippine plant species, one might assume that the Culion cycad's Latin name was trivial-a name likely plucked in the interest of speed to publication.

Whether or not the finalized Latin name of the cycad was special to Merrill is not the focus of this paper. He is alleged to have named a new Philippine plant species after inedible rodent parts from a collecting trip on the island of Mindoro (Hay 1998, 16). Instead, I rather attend to the archival record to chart an example of the processes of Latin naming during the U.S. colonial period of the Philippines. These names are not inconsequential to international botany, and the Culion species is still known as $C$. wadei to cycad specialists today. As such, it is important not to take at face value the names upon which contemporary intellectual communities rely, particularly for the Philippine plant species that have a more generous archival record than others. These records can be sparse and not all capture the distinctive local and international political climate of their time. For this article, I unearth bits of these problems through existing correspondence on the cycad. What may seem like routine 
cover letters to specimens sent between herbaria, specimen envelopes, and scrawled notes carry the residue of institutional struggles, political intrigue, and pivotal global moments. The existing correspondence, therefore, is insightful when investigating the role that scientists played in the ordering of plant life in the colony.

${ }^{1}$ All correspondence from the Elmer D. Merrill Papers at the Archives of The New York Botanical Garden.

${ }^{2}$ Noah Theriault (Department of History, Carnegie-Mellon University) brought this to my attention by personal communication, December 8, 2018. I thank him for the citations.

\section{TRACKING THE CULION CYCAD}

Elmer D. Merrill was first sent to the Philippines in 1902 and was a botanist at the Bureau of Science, first named the Bureau of Government Laboratories (f. 1901), from 1906 up through his departure from the Philippines in 1923. While at the bureau he published extensively and at one point was an active professor at the University of the Philippines. He was named director of the Bureau of Science during his final four years in the Philippines after which he left for a deanship in the College of Agriculture at the University of California, Berkeley.

While at the University of California, Merrill completed and published his An Enumeration of Philippine Flowering Plants, an extensive multi-volume work on Philippine flora. On the first page of Volume I of Enumeration, Merrill references a cycad he collected but could not effectively identify. He details, "In open grasslands at low altitudes. A curious species, of which only the leaves are known, perhaps representing the above Australian species," Cycas cairnsiana (Merrill 1922, 1). Merrill recounted first observing the cycad while surveying lands with other scientists for the establishment of a leper colony in the Philippines. In 1902, he and other U.S. scientists visited the province of Paragua, which was later renamed Palawan. It was on the northeastern island of Culion, which indeed became the site for the U.S. leper colony, that Merrill collected samples of the cycad.

According to historian Rene Escalante, colonial health officials identified leprosy as a pressing concern upon U.S. arrival to the Philippines. Health officials sought a location that was spacious enough for agriculture and could accommodate hospitals, residences, and recreational facilities. Furthermore, the location of the leper colony needed to have an existing harbor and an inaccessible entry-and-exit point to prevent escape. Conversion of Culion into a leper colony began in 1902 and in 1904, the island was declared a formal reservation. Three years later, the Philippine Commission formalized forced apprehension and detention of all those suspected or diagnosed with leprosy (Escalante 2016, 95).
The leper colony gained international popularity for its research, and historians have investigated how colonial health officials tried to produce as much of a normal life as possible for its residents. The "colony within a colony" had its own orchestra and its own monetary system so that money exchanged on the island never left. The likelihood of leaving the colony after treatment, however, was slim, and permanent isolation was a marked feature of institution (Dado 2016).

Between 1902 and the publication of Enumeration in 1925, published mention of the cycad from Culion was made in a 1911 article in the Philippine Journal of Science by Fred Foxworthy. In his 1903 A Dictionary of the Plant Names of the Philippine Islands, Merrill lists the Tagalog word pitogo, but indicates its reference to Cycas circinalis (97). It was not until 1923 that a more determined study of the Culion species would reemerge and requests to find more sample material from the island surfaced.

Plant physiologist William Henry Brown requested that researchers stationed in Culion try to find more samples of the cycad. Brown was appointed as director of the Bureau following Merrill's leave and held the post for nine years. One of the Culion researchers Brown contacted was Herbert W. Wade, who first arrived to the Philippines in 1916. After working as a bacteriologist and pathologist at the bureau and holding a teaching post at the College of Medicine and Surgery of the University of the Philippines, Wade moved to Culion in 1922. In 1924, Wade relayed the pleasurable news that he photographed and collected proper cycad specimens for Brown. Wade referenced what looked like the original cycad Merrill observed in 1902:

For reference, I would say that this cycad is the one that Dr. Perkins [another Culion researcher] and I found while hunting for one that Mr. Merrill wanted. Quite some years ago he was in Culion and went from Halsey Harbor to the Cogonal Grande, a few kilometers north and west of the Harbor. He collected a leaf and asked us to get more material for him. We hunted the place over, going there both from Halsey Harbor and from the east, but could find nothing that matched his leaf, though we thought we had it when we found many specimens of a cycad very different from the coast type (H.W. Wade to W.H. Brown, September 18, 1924).

While Brown had these new cycad samples from Wade at the Bureau of Science, Merrill had separately asked another researcher to collect samples on his behalf. Merrill commissioned the help of Albert W.C.T. Herre, an ichthyologist and lichenologist. Herre was appointed Chief of Fisheries at the bureau in 1920 and spent a decade of research in the Philippines. Merrill received and reviewed the 
Herre samples while in New York where he took a directorship at the New York Botanical Garden (NYBG) after leaving the University of California in 1930. After Merrill received the specimen collections from Herre, he communicated with Brown indicating his own enthusiasm regarding what he determined to be a new species. In August of 1931, Merrill wrote to Brown telling him that he had found the "undoubtedly undescribed species," which he had tentatively named $C$. herrei. He wanted to clarify, however, if Brown had planned to describe the species himself or in cooperation with Eduardo Quisumbing, another botanist stationed at the Bureau of Science (Merrill to Brown, August 10, 1931).

\section{The Politics of Latin Nomenclature}

The benefit of the modern moment assures us that the species was, in fact, named $C$. wadei. The difference, however, is still worthy of pause. Two different U.S. colonial scientists could have been memorialized with this plant specimen. Historians have studied Latin naming conventions at length and how these conventions have signaled acts of status-making and status-giving. Aside from names drawn from morphological features of species, others have tended to honor scientists, locations of species collection, collectors, and patrons. Refuting Londa Schiebinger's "linguistic imperialism" thesis (2007), wherein plant names were given a Latin name in service to a science and scientists whose roots are entangled in European intellectual endeavor, Alexandra Cook argues that Carl Linnaeus and his son "engaged in cross-cultural nomenclature," particularly in the naming of various species collected in China, whose names were nonEuropean or drawn from local application of the species (Cook 2010, 133). Though similarly, Schiebinger examines naming exceptions by tracking Quassia amara, named after the Surinamese healer Graman Quassi (Schiebinger 2007, 211-214).

Isolated focus on Latin nomenclature, as I see it, fails to account for the enduring nomenclatural practices that persist despite it. While the ideology behind Latin binomial nomenclature may be global, it has not succeeded in erasing the particular, common, and I would argue, more widely used names associated with plant species, no matter the variety of languages. Still, Cook cites the work of Staffan Müller-Wille to insist that Latin binomials were conceived to "mediate between different cultures rather than to service the interests of a particular one" (Müller-Wille 2005, 48). To suggest that cosmopolitan botany does not have a particular culture is supercilious. The claim that an international science mediates other cultures without impressing its own politics, conventions, or moral economy (Daston 1995)-a claim to non-situated objectivity (Haraway 1988)-loftily discounts the geographical, intellectual, and human origins of nomenclatural conventions.

The global imperial field of the early twentieth century was marked by inter- and intra-imperial relations that, as Julian Go explains, influenced "new circuits of exchange and movement, constituted by the flow of goods, people, and ideas within and among imperial domains" (Go 2003, 20). While the exchange of botanical material between herbaria had been a common practice prior to the emergence of this newer imperial field, botanical material could consolidate and reinforce the relationships of scientific institutions in colonies and in metropoles. As inter-imperial conferences at the turn of the century emerged to establish a shared conduct and ethics among imperial states (Go 2003, 21-22), the International Botanical Congress (IBC) sought to more effectively standardize nomenclatural conventions. First held in Brussels in 1864, the IBC moved to establish the "International Rules of Botanical Nomenclature" at its convening in Vienna in 1905. In 1926, the IBC assembled for the first time across the Atlantic in New York. In the cycad letters, references are made to the Fifth International Botanical Congress of 1930 in Cambridge, at which Merrill was the Vice President and Chairman of the Section on Nomenclature. Proceedings of the IBC noted that the Section on Nomenclature was "very ably" led by Merrill, who had "undoubtedly the most difficult position in the entire congress" (Yuncker 1930, 65). The Fifth Congress is significant to the history of international taxonomy since competing schools merged nomenclatural conventions that produced a more trans-Atlantic system. For example, the "American code" that espoused the significance of a type concept-that is, the identification of the specimen that is representative of a taxon-became a considered part of international practice. With the approach of the Sixth International Botanical Congress held in Amsterdam in 1935, botanist Marius Jacob Sirks wrote, "[T]he need of an international cooperation is becoming more and more sensible," remarking that the previous meetings demonstrated "a strong feeling for international affinities" (M.J. Sirks to the National Research Council, August 20, 1934). In 1934, the majority of member-nations that comprised the Union of Biological Sciences and its Botanical Section were in Europe, with the exception of Japan and South Africa (ibid.). Indeed, globalist or internationalist bodies subscribe to or espouse a particular culture, even if superficially unbound by national identity. The history behind nomenclatural conventions reminds us that names are entwined with the veneration of scholarly endeavor within a broader field of imperial relations and international politics.

Brown responded immediately to Merrill's letter with a twopage explanation as to why the new species should be 
named after Herbert Wade. In the letter, Brown emphasized that Wade "might feel I have been negligent and let someone else to describe it under another name" (W.H. Brown to E.D. Merrill, September 26, 1931). Brown enumerated Wade's collected material at length:

At my request he made a very full and excellent collection including leaves materials, male cones, and female sporophylls, and an entire female head which I have in formalin. Also he took quite a number of very excellent photographs of this species...In addition Wade brought up to me the large male and female plants from which he collected female sporophylls and male cone. He had to carry these on his back across the island of Culion and then set them up in his place and got them grow [sic]. Afterwards he brought them to Manila where I have them growing in the Bureau of Science (ibid.).

Further on, he explained that he would have published a description of the interesting species but could not do so because he could not collect proper developmental material from the cycad specimens growing on bureau grounds. Brown closed the letter conceding that he would send his collected material, photographs, and manuscript descriptions to Merrill. "As far as I am concerned," Brown added, "it is immaterial whether you or I or we together describe the species. Perhaps the last would be a good arrangement as I certainly want somebody to write the diagnosis for me and I have much data which should be included in the original description. Of course, I cannot object if you publish as the species was your find" (ibid.).

From the correspondence, one can deduce that Brown and Merrill engaged in the very academic propriety in which many early twentieth-century botanists participated. This polite ethos could obfuscate the professional competitions that happened in the botany discipline. Based on the sources, Brown evidently began collecting material on the same cycad that had been under Merrill's study. But due to Merrill's absence from the Philippines, Merrill could not oversee collection or cultivation of the species. While I do not suggest that Brown collected material unbeknownst to Merrill, the correspondence makes clear that Brown would have published first had his specimens properly pollinated. Publication on a new species, as is understood in the natural sciences today, is not an immaterial feat but in fact a careermaking accomplishment.

\section{Durable Correspondence Networks}

Much of the success of Merrill's publication on the new cycad was due to Merrill's enduring professional relationships with
Filipino botanists and U.S. scientists stationed in the Philippines. Though Brown wrote that he would send his cycad materials to Merrill, various letters suggest that the arrival of said materials was inexplicably delayed. Merrill, instead, looked to his Philippines-based collaborators for support. Though their archives are not as voluminous, collection logs, current herbaria databases, and publications reference several of the men whose work contributed to U.S. colonial botany in the Philippines. Chief among Merrill's regular correspondents was Eduardo Quisumbing. Their friendship began in the early 1900s and continued throughout the remainder of Merrill's life. Quisumbing trained at the College of Agriculture, now known as the University of the Philippines, Los Baños, in the province of Laguna before completing his doctoral work at the University of Chicago in 1923. After working briefly with Merrill at the University of California, Quisumbing returned to the Philippines where he worked at the Bureau of Science-and in many of its divisions following major institutional splits—through 1961. For decades, Quisumbing and Merrill maintained regular correspondence, which has provided insight on pivotal historical moments in the Philippines such as World War II, the Battle of Manila, and the reconstruction of the capital in the 1940s and 1950s (Gutierrez 2018).

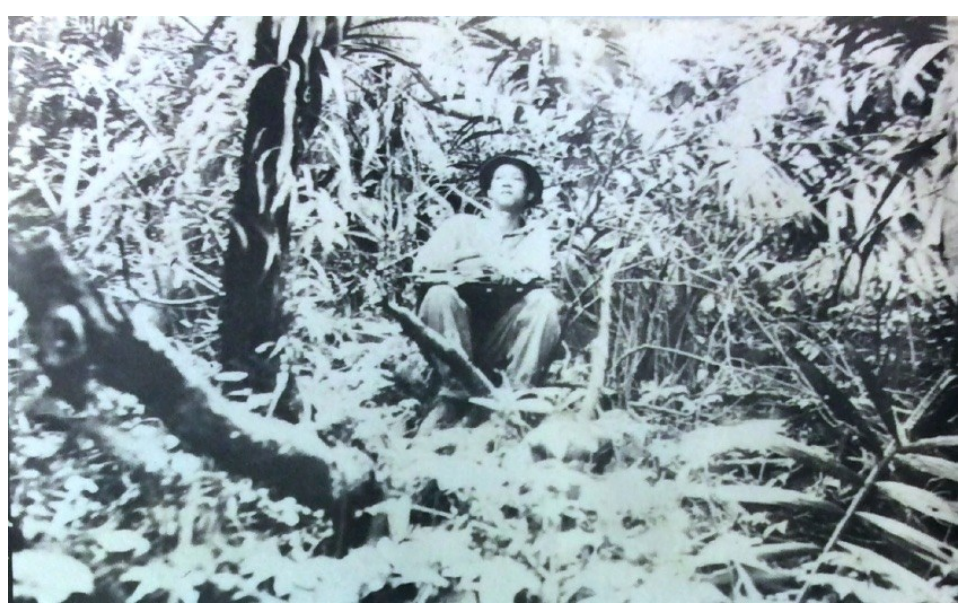

Figure 2. "E. Quisumbing and a rattan," August 23, 1913, Mt. Makiling, Laguna. Frank Gates Papers, Photographs 1912-1915, Box 1, Bentley Historical Library, University of Michigan.

In their 1930s exchanges, Merrill and Quisumbing mutually provided updates on the new cycad. Merrill looked to Quisumbing to send needed material when parcels from Brown were either delayed or incomplete (E.D. Merrill to E. Quisumbing, August 8, 1932). In a June 1932 letter to Quisumbing, Merrill did not communicate that the name-C. wadei-was a directive by Brown. He explained that he had tentatively named it $C$. wadei and had simply forgotten to label it as such after Herre's collection arrived to New York (E.D. Merrill to E. Quisumbing, June, 1, 1932). Yet, what become notable in the letters between Quisumbing and 
Merrill more so are the ongoing references to institutional and budgetary troubles.

The Great Depression, in particular, is most severely felt in the letters between Merrill and some of his correspondents during Merrill's tenure at the NYBG in the early 1930s. According to one of Merrill's biographers, at the outset of the depression the institution was "inadequately financed with obsolete and worn-out equipment and with a heavy overdraft on capital funds used for operating expenses" (Robbins 1958, 287). The "[d]rastic economies" necessitated by the Great Depression nevertheless motivated public relief assistance for the NYBG, which allowed the institution to rehabilitate its facilities and grow its herbarium collection (Robbins 1958, 277 -288). Still, collaborative projects with outside institutions were stalled. In February of 1932, Merrill informed then director of the Royal Botanic Gardens, Kew, Arthur W. Hill, that the likelihood of funding the completion of a flora of British Guiana-a project in which Merrill had taken keen interest-was slim due the impact of the economic depression on U.S. funding agencies (E.D. Merrill to A.W. Hill, February 26, 1932). The following year, Julián Acuña Galé, chief of the Agricultural Experiment Station in Santiago de las Vegas, Cuba, wrote to Merrill appealing on behalf of botanical collector Dr. Juan T. Roig, who was in need of employment after political unrest led to his losing his teaching position. Acuña suggested, "I have thought that you might perhaps help him in some way by giving some occupation, for example by asking him to collect plants for the N.Y. Botanical Garden in some particular locality not well explored in the island" (J. Acuña to E.D. Merrill, November 6, 1933). In response to Acuña, Merrill mourned, "[O]ur financial condition does not permit of any such arrangement at the present time" and recommended that Roig consider work as a professional collector so he could sell sets of duplicate specimens to U.S. and European institutions (E.D. Merrill to J. Acuña Galé, November 28, 1933). Merrill noted, however, that with the "prevailing economic depression," most institutions would likely not have the funds to purchase duplicates (ibid.).

What was approximately a decade-long worldwide economic downturn impacted the labors of scientists, especially those who relied on public moneys. This led to the reduction of salaries of government employees in the colonial Philippines. In his June 1932 letter to Quisumbing, Merrill sympathized, "I am sorry to learn of the reductions of salaries affecting Government employees in Manila...We have already been obliged to make some reductions in salaries at The New York Botanical Garden. The times are indeed distinctly difficult and one can scarcely foretell what is in store for us if the economic depression continues much longer" (Merrill to Quisumbing, June 1, 1932).
During these years, massive institutional changes were underway at the Bureau of Science. Of the proposed changes the most startling one, according to Quisumbing, was the transfer of the bureau's herbarium to the College of Agriculture. These proposed changes coincided with the approach of the Philippine Commonwealth. The Philippine Commonwealth began with the passage of the TydingsMcDuffie Act in 1934. However, the act was preceded by the Hare-Hawes-Cutting Act that had declared Philippine independence a year prior. On the state of political and institutional affairs in the Philippines at the time, Quisumbing wrote, "With the Hawes-Cutting Bill on Independence and plans on reorganization of the Bureau of Science, I am afraid that some drastic rearrangements will happen" (E. Quisumbing to E.D. Merrill, January 23, 1933). The HareHawes-Cutting Act was initiated by both Filipinos who sought independence and by U.S. agriculture stakeholders who opposed competition with tariff-free sugar and coconut oil imports from the Philippines. However, the Philippine Senate did not pass the act. Instead, its successor, the better-known Tydings-McDuffie Act, passed and heralded the Philippine Commonwealth.

The onset of Philippine independence shook the halls of the Bureau of Science. It is in the cycad letters that we gain glimpses of how certain scientists reacted to the political changes afoot in the Philippines. To Merrill, Quisumbing detailed the uncertainty of independence and of the government plans that threatened various research sections of the bureau. Among them was the proposed transfer of the herbarium. Quisumbing explained how he and pharmacologist León María Guerrero "fought the idea" and that it would "be the most tragic mistake of the government" if it were actualized (ibid.). U.S. agriculturist Edwin Copeland, according to Quisumbing, had been at the forefront of the effort to move the herbarium to Los Baños, and Copeland had threatened authorities if the herbarium were not relocated to Laguna. "All these happenings as you realize," Quisumbing relayed to Merrill, "are not conducive to fruitful research and work. It has been the cause of worries of many employees yere [sic] and it is beginning to undermine me. Dr. Guerrero who is against this reorganization scheme is frantically mad. I do hope, however, that the authorities concerned will come to their senses some day and give up their pet plans" (ibid.).

A year after Quisumbing's letter to Merrill, Quisumbing sent a confidential copy of a scathing 17-page memorandum entitled "Dr. Copeland's Dream of 30 Years Shattered" (E. Quisumbing to E.D. Merrill, August 14, 1934). According to

\footnotetext{
${ }^{3}$ Quisumbing and Merrill's notable professional relationship has been recorded by Quisumbing biographers. See Asis 1973; Barroga-Jamias 2000, 164-174.
} 


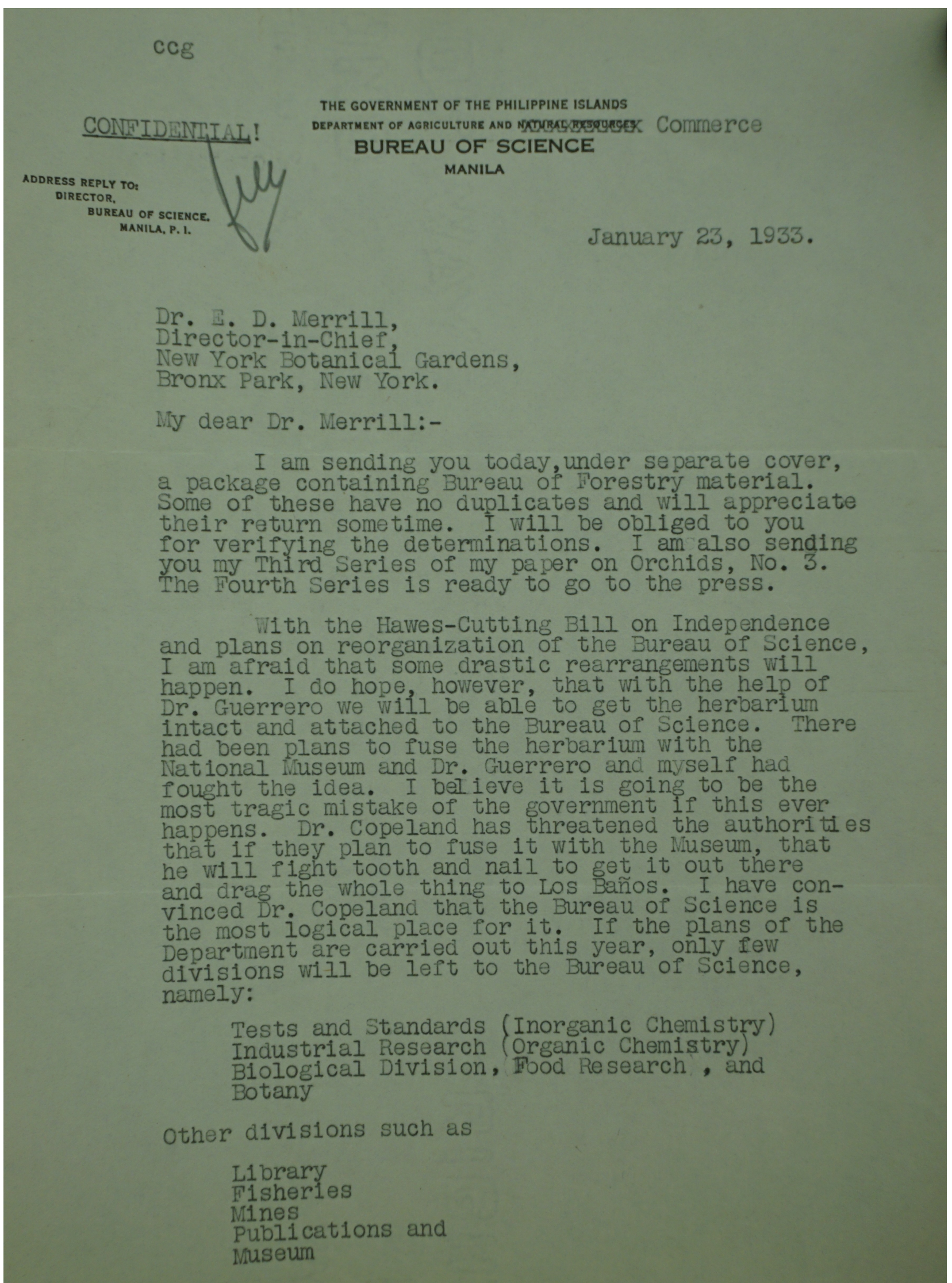

Figure 3. Letter from E. Quisumbing to E.D. Merrill, January 23, 1933, EDMP, Series 2, Box 3, Folder 15, Archives of The New York Botanical Garden. 
Quisumbing, Copeland had allegedly sought to fuse the College of Agriculture, the Bureau of Agriculture, and the Bureau of Science under his own leadership, which Quisumbing remarked was a "matter of record" throughout the several decades Copeland was stationed in the Philippines (E. Quisumbing to J.B. Vargas, 1934). In the memorandum, Quisumbing continued:

It is an old, homely, but immensely true saying, that you cannot teach an old dog new tricks, nor can you change the nature of thorn [sic] by calling it a rose and so we see, in the year of our Lord 1934, the same old schemes and ambitions of Dr. Copeland again at work, fermenting, fermenting, but making a very poor excuse for 'good beer.' He is trying to build for himself a botanical institute at Los Baños, with the economic garden as a pretext and a nucleus to enable him to carry out his frustrated dream and to justify his prolonged stay in the Philippine Islands. Under the financial situation of the Philippines, I believe it is a waste of both time and money to spend $\mathrm{P} 12,000$ for the salary of a man for the kind of work he is doing (ibid.).

Citing "mental derangement" among other insults, Quisumbing lambasted Copeland for Copeland's public critiques of the Bureau of Science and his sustained effort to move the herbarium to Los Baños. Such a move, Quisumbing warned, would be for the "aggrandizement of one man" and not for the sustained contributions to the wider scientific community the herbarium offered through its location at the Bureau of Science in Manila (ibid.).

Besides Quisumbing, other civil service employees in the Philippines maintained regular contact with Merrill and communicated similar feelings of institutional unrest. Because of the economic downturn felt in Manila and elsewhere in the Philippines, several men appealed to Merrill to work with him in New York, where they believed there was better remuneration, more research opportunities, and fewer political squabbles. Ceferino D. Montejo, an associate of Merrill's living on the island of Leyte, wrote to Merrill asking what life Filipinos typically lead in New York (C.D. Montejo to E.D. Merrill, October 20, 1931). "Is the racial feeling so keen as in the Pacific coast way down in San Francisco or Los Angeles, or Watsonville, where the riots were staged?" he asked. Curious if he could "get along all right" in New York with only enough fare to take him "across the Atlantic," Montejo inquired if Merrill could be relied upon so that he "may be able to get along with some thing to make a living to make body and soul meet together." At the close of the letter, Montejo requested "a nice reply, a sort of Father to Son heart to heart talks [sic], a tete-a-tete to give [him] in [his] proposed plan to go New Yorkwards." Leodegario E. Hachero, a botanical collector from Surigao who was trained by U.S. collector Chester A. Wenzel, similarly reached Merrill for guidance. Hoping to continue his work in plant collection and preservation, Hachero offered to assist with any of Merrill's flora work on the island of Mindanao (L.E. Hachero to E.D. Merrill, January 1, 1934). Yet, Merrill responded to both Montejo and Hachero with a bleak depiction of the employment and research environment in the U.S. and could not promise any Philippines-based collector or civil service employee gainful employment. To Montejo, he advised against traveling to New York under any circumstance unless he had the financial means to support himself in the United States (E.D. Merrill to C.D. Montejo, November 30, 1931). "I can make no definite promises of employment at The New York Botanical Garden, because of the fact that owing to our financial situation retrenchment rather than expansion must be followed, and it seems highly probable that we may have to dispense with the services of some of the employees of the Garden in the very near future," he lamented. Merrill added, however, that in his two years in New York he "observed no anti-Filipino feeling" (ibid.).

In some appeals, correspondents communicated the bureau struggles, which escalated in 1934 with the forced departure of Brown from his directorship. While Merrill's obituary of Brown states that Brown retired from the bureau (Merrill 1939, 532), a letter from C.J. Humphrey, a bureau researcher who published on fungi, suggests otherwise. It is from this letter one may piece together a partial picture as to why the cycad material was delayed in reaching Merrill. Humphrey shared that the bureau's problems culminated in "the forced resignation of Dr. Brown" and that "the independence agitation... increased the Anti-American feeling, and a feeling of self-sufficiency on the part of the natives, which is strongly antagonistic to any Americans in government employ" (C.J. Humphrey to E.D. Merrill, January 24, 1934). Humphrey shared that he and other U.S. scientists speculated that Brown worked with Secretary Jorge B. Vargas to create "an Anti-American frame-up" (ibid.) among the government ranks. Later in the same letter, Humphrey confided how Brown may have colluded with his "henchman" Copeland to stoke feelings of animosity among the scientists. One of the gravest accusations running through the bureau halls, according to Humphrey, was that scientists were maintaining private collections even though all government employees were required to centralize collections with the bureau (ibid.). On the state of the Bureau of Science, Herre shared similar regrets with botanical collectors Mary Strong and Joseph Clemens, bemoaning, "Poor Bureau of Science. Brown was let out at last, but too late to save the institution I fear. I was proud of the Bureau of Science, but not any more; it is a wreck" (A.W.C.T. Herre to 
M.Strong and J. Clemens, March 3, 1934).

Soon after receiving Humphrey's letter and a similar letter from Herre detailing the divisive events at the bureau, Merrill wrote to another bureau researcher, Richard C. McGregor, asking about the fate of the Philippine Journal of Science. Merrill made clear that he was not asking for "inside information" on Brown's sudden departure. Instead, he wanted to determine where he would publish his complete manuscript on the cycad should the journal dissolve.

A short time ago I had a long letter from Herre mostly about what has happened to the Bureau of Science, and what happened to Brown; with [Arthur F.] Fischer acting as Director of what was left of the old unit. This letter isn't a bid for inside information, but rather to find out, if possible, what may happen to the Journ. Sci. Is there any chance of its being discontinued? I have in rough draft a paper on a new Cycas from Culion. What shall I do, finish it and send it on for publication, or try to find a place for it elsewhere? (E.D. Merrill to R.C. McGregor, February 19, 1934).

Though there is a lengthy gap in Merrill's cycad correspondence between his last letter to McGregor and his final letter written as director at the NYBG, Merrill sent his final manuscript and the original type specimens back to Manila in 1935 for Quisumbing's and Brown's review. The description of the cycad appeared in an issue of the sixtieth volume of the Philippine Journal of Science a year later.

In his 1936 description, Merrill credits Perkins and Wade for spotting the live cycad species on Culion in 1923, two decades after Merrill's initial sighting (Merrill 1936, 233-234). He explains that "abundant material" had been collected by Brown, though it is uncertain in the existing correspondence record when Brown may have personally visited Culion. Such abundant material from the island was likely from Wade's collected samples that were sent to Manila. Merrill proceeds in the article to add that it was Herre's collection from April 1931 that seemed to be the missing material for producing a description: "In April 1931, leaves with female sporophylls and fruits were collected by Dr. A.W.C.T. Herre in Culion. It was the receipt of this last collection for identification that reminded me of the unsolved problems associated with this interesting cycad, which lead me to communicate with Dr. W.H. Brown, asking for the load of the available material that would enable me to prepare a reasonably complete description" (Merrill 1936, 234). Given the material and J. Schuster's (1932) incorrect identification of the Culion species, Merrill considered the cycad "worthy of specific rank" (Merrill 1936, 234). Preceding the Latin description, Merrill mentions, "In describing this as Cycas wadei I would explain

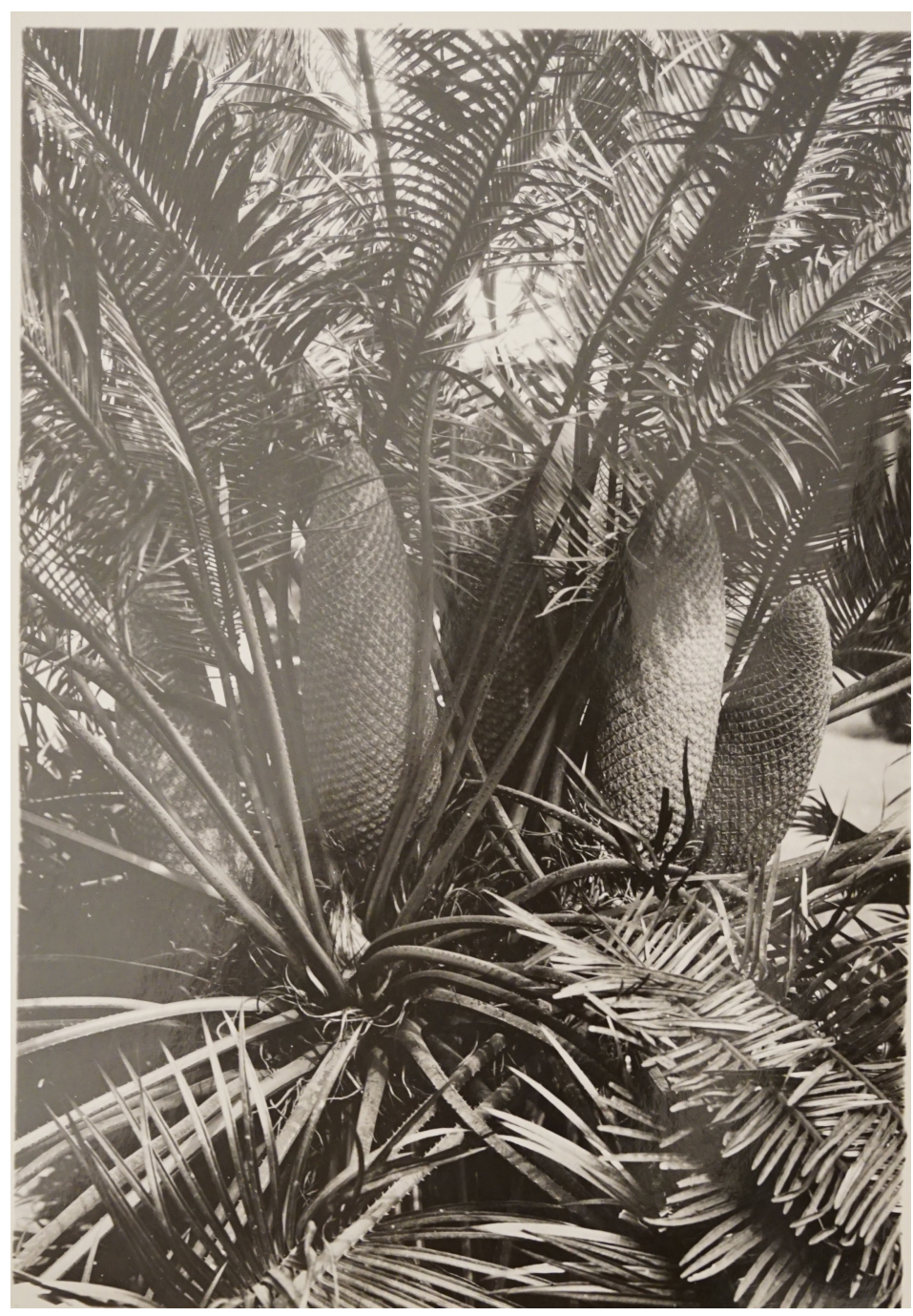

Figure 4. Image of live $C$. wadei and its male cones. EDMP, Series 3 (Oversized), Archives of The New York Botanical Garden.

that the specific name is selected to commemorate the services of Dr. H. Windsor Wade, for many years in charge of research at the Culion Leper Colony, to whom we are indebted for much of our information regarding the plant, as well as for photographs, mature fruits and other botanical material, and maximum and minimum measurements of various plants as they occur in nature" (ibid.).

\section{CONCLUSION}

The intellectual history of Cycas wadei takes us through the political interests of U.S. and Filipino scientists in the early twentieth century. It demonstrates the interpersonal connections among some of the better-known personalities in Philippine science, offering a glimpse into the years leading to the Philippine Commonwealth and the anxieties felt by Filipinos and Americans alike. It likewise includes the political struggles experienced in Philippine and U.S. institutions during the Great Depression. Such a history 
broadens our understanding of the constellation of institutions such as the Bureau of Science, the Culion leper colony, the Philippine Journal of Science, and the New York Botanical Garden that advanced Philippine botany and participated in the multi-scalar politics of Latin nomenclature. Dried specimens of the cycad and information on the species moved through these institutions, reminding us that the project of U.S. colonial science in the Philippines operated within and outside of the geographical bounds of the archipelago. As Julian Go has articulated, there was a "larger field of action and interaction in which the U.S. colonial state in the Philippines was embedded" (Go 2003, 16), one that was responsive to and constitutive of the global imperial field of the early twentieth century. The politics of nomenclature through this case study illuminates those scales of interaction-human, institutional, global-that marked the formalization of $C$. wadei.

Yet, no matter how formalized the Culion cycad's name is in international botany, threat to the species looms. In 1934, Quisumbing emphasized that the herbarium of the Bureau of Science was "one of the greatest of the world and is known the world over. It could never under any circumstance be replaced if destroyed for the simple reason that the types of new species and the specimens of unica which it contains are not susceptible of duplication as any scientific man knows" (Quisumbing to Vargas, 1934). Yet, nearly a decade after publication on the Culion cycad, the Bureau of Science was razed by mostly U.S. artillery during the Battle of Manila. The cycad's type specimen was likely destroyed during World War II (D.A. Madulid to B.G. Briggs, September 9, 1993). In a 1993 letter from Domingo Madulid, former botany curator of the National Museum of the Philippines, to the Royal Botanic Garden Sydney (RBGS), Madulid wrote of the $C$. wadei type specimen, "[W]e regret to inform you that we do not have these specimens in our collection. The type specimens of these specimens were probably included in the destruction of the PNH [Philippine National Herbarium] during the Second World War" (ibid.). Madulid's letter and colored photographs of the cycad take the place of a typical herbarium specimen sheet at the National Herbarium of New South Wales located in the RBGS. The destruction of the Battle of Manila took with it many of the type specimens that were career-making for dozens of U.S. colonial scientists. As Quisumbing once illuminated of the herbarium, "It is not merely a mass of dried, named plants. It is an aggregation of material made vitally alive by the reason of the commentaries, notes and annotations of the men who described the plants. These notes often in their own hand writing or that of equally able successors in the field of research and criticism" (Quisumbing to Vargas, 1934). Quisumbing's humanistic account of the herbarium and its collection stresses the meaningful labors memorialized by hand, aptly preserved and communicated for generations of scholars. The vitality of such material, as he claims, is dependent on the historical sensitivity of the annotative acts of current taxonomists.

Currently, C. wadei is a critically endangered species and with a steadily decreasing population, only numbers 5,000 mature specimens (Hill 2010). Any destructive development or ecological disaster to its locality on Culion could mean the loss of the entire species. Domingo Madulid and Esperanza Maribel Agoo note that the species is threatened by fire set seasonally for cattle grazing and by human settlement (Madulid \& Agoo 2009, 102). Similar can be said of other cycads, like $C$. lacrimans and $C$. mindanensis, which grow in locations with rich nickel deposits that put the species at risk due to extractive activities (Agoo et al. 2018, 536).

Once considered by some as "the last frontier" of the Philippines, the province of Palawan is no stranger to this kind of environmental distress. The political ecology has been marked by longstanding resource extraction, increased tourism, and equally so, environmental activism. The heightened mining activity in the province has sparked heated debates among various stakeholders. The highprofile murder of journalist and wildlife veterinarian Gerry Ortega in Puerto Princesa in 2011 is only one of the startling indications of the ongoing politically charged environmental unrest in the province. Histories that track the discovery, collection, and description of Philippine plants have the opportunity to highlight not only the vast endemic flora to the archipelago but also what the continued existence-or threatened nonexistence-of these species can mean. Indeed, the very threats to the Philippine cycad species occur on multiple scales of human and exploitative interaction, reminding us that the intellectual interest in a species is beholden to threats to its survival.

${ }^{4}$ For more on the political ecology of Palawan, see Eder \& Evangelista 2014.

\section{ACKNOWLEDGEMENTS}

A version of this article will appear in the forthcoming anthology Empire and Environment: Confronting Ecological Ruination in the Asia-Pacific and the Americas. This project began under the fruitful mentorship of Esperanza Maribel Agoo and Domingo Madulid. I am grateful for the generosity of the Archives of The New York Botanical Garden and to the indexing work of my research assistants at DLSU-Manila: K. Aurelio, D. Concha, P. DeVries, J. Gatdula, H. Narvas, and N. Ty. I appreciate Irineo J. Dogma, Jr. and Rey Donne Papa for inviting me to submit this history piece; the research and writing of which could not have been completed without support from the Social Science Research Council's 
International Dissertation Research Fellowship, with funds provided by the Andrew W. Mellon Foundation, and the Fulbright-Hays Doctoral Dissertation Research Abroad program. This article is dedicated to Hermes G. Gutierrez, the first systematist I came to know.

\section{LITERATURE CITED}

\section{Archival Collections}

Bentley Historical Library, University of Michigan Frank Gates Collection

Esperanza Maribel Guiao Agoo Collection

Archives of The New York Botanical Garden Elmer D. Merrill Personal Papers

Series 2 (Correspondence), Boxes 1-3

Series 3 (Oversized)

\section{Published Sources}

Agoo, E.M.G., D.A. Madulid \& J.R. Callado, 2018. Novel species of Cycas (Cycadaceae) from Mindanao Island, Philippines. In: Cycad Biology and Conservation: The $9^{\text {th }}$ International Conference on Cycad Biology. The New York Botanical Garden, Bronx, New York. Pp. 529-539.

Appleby, J.H., 1983. Ginseng and the Royal Society. Notes and Records of the Royal Society of London, 37(2): 121145.

Asis, C.V., 1973. Quisumbing and friend. Natural and Applied Science Bulletin, 27(1-2): 1-73.

Barnard, T.P., 2015. The Rafflesia in the natural and imperial imagination of the East India Company in Southeast Asia. In: Damodaran V., A. Winterbottom \& A. Lester, (eds.), The East India Company and the Natural World. Palgrave Studies in World Environmental History, Palgrave Macmillan, London. Pp. 147-166.

Barroga-Jamias, S.F., 2000. Eduardo A. Quisumbing: Botanist par excellence and Father of Philippine Orchidology (1895-1986). In: Department of Science and Technology-National Academy of Science and Technology, National Scientists of the Philippines (19781998). Anvil Publishing, Inc., Manila. Pp. 164-174.

Carney, J.A., 2001. African rice in the Columbian Exchange. The Journal of African History, 42(3): 377-396. , 2002. Black Rice: The African Origins of Rice Cultivation in the Americas. Harvard University Press, Cambridge. 240 pp.

Cook, A., 2010. Linnaeus and Chinese plants: A test of the linguistic imperialism thesis. Notes and Records of the Royal Society of London, 64(2): 121-138.

Dado, V.A., 2016. Spaces and boundaries in Culion: Mobility amidst segregation. In: Diokno, M.S., (ed.), Hidden Lives, Concealed Narratives. National Historical Commission, Manila. Pp. 113-139.

Daston, L., 1995. The moral economy of science. Osiris, 10,
Constructing Knowledge in the History of Science: 2-24. 2012. The sciences of the archive. Osiris, 27: 156187.

De Jesus, E.C., 1998. The Tobacco Monopoly in the Philippines: Bureaucratic Enterprise and Social Change, 1766-1880. Ateneo de Manila University Press, Quezon City.

De Laubenfels, D.J. \& F. Adema, 1998. A taxonomic revision of the genera Cycas and Epicycas gen. nov. (Cycadaceae). Blumea, 43: 351-400.

Eder, J.F. \& O.L. Evangelista, (eds.), 2014. Palawan and Its Global Connections. Ateneo de Manila University Press, Quezon City. 392 pp.

Escalante, R.R., 2016. American public health policy on leprosy, 1898-1941. In: M.S. Diokno, (ed.), Hidden Lives, Concealed Narratives: A History of Leprosy in the Philippines. National Historical Commission, Manila. Pp. 87-110.

Folch, C., 2010. Stimulating consumption: Yerba mate myths, markets, and meanings from Conquest to present. Comparative Studies in Society and History, 52 (1): 6-36.

Foxworthy, F., 1911. Philippine gymnosperms. Philippine Journal of Science, 6 (3): 149-178.

Go, J., 2003. Introduction. In: J. Go \& A. Foster, (eds.), The American Colonial State in the Philippines: Global Perspectives. Duke University Press, Durham. Pp. 1-42.

Gutierrez, K.C., 2018. Rehabilitating botany in the Postwar moment: National promise and encyclopedism of Eduardo Quisumbing's Medicinal Plants of the Philippines (1951). Asian Review of World Histories, 6: 33-67.

Haraway, D., 1988. Situated knowledges: The science question in feminism and the privilege of partial perspective. Feminist Studies, 14: 575-599.

Hay, I., 1998. E.D. Merrill, From Maine to Manila. Arnoldia, 58(1): 11-19.

Hill, K.D., 2010. Cycas wadei. The IUCN Red List of Threatened Species 2010. http://dx.doi.org/10.2305/ IUCN.UK. 2010-3.RLTS.T42097 A10631294.en. Accessed April 25, 2018.

Madulid, D. \& E.M.G. Agoo, 2009. Taxonomy and conservation of Philippine Cycads. Blumea, 54: 99-102.

Merrill, E.D., 1903. A Dictionary of the Plant Names of the Philippine Islands. Bureau of Government Laboratories, No. 8. Bureau of Printing, Manila. 196 pp. , 1922. An Enumeration of Philippine Flowering Plants, Volume 1. Bureau of Printing, Manila. 1936. A new Philippine species of Cycas. Philippine Journal of Science, 60(3): 233-239. 1939. William Henry Brown. Science, 90(2345): 531532.

Müller-Wille, S., 2005. Walnuts in Hudson Bay, coral reefs in 
Gotland: The colonialism of Linnaean botany. In: Schiebinger, L. \& C. Swan, (eds.), Colonial Botany: Science, Commerce and Politics in the Early Modern World. University of Pennsylvania Press, Philadelphia. Pp. 34-48.

Osseo-Asare, A.D.A., 2014. Bitter Roots: The Search for Healing Plants in Africa. University of Chicago Press, Chicago. 300pp.

Parsons, C.M., 2016. The natural history of colonial science: Joseph-François Lafitau's discovery of ginseng and its afterlives. The William and Mary Quarterly, 73 (1): 37-72.

Revel, N., 1990. Fleurs de paroles: Histoire naturelle palawan (Tome I: Les dons de nägsalad). Centre National de la Recherche Scientifique and Ministère des Affaires Étrangères, Paris.

Robbins, W.J., 1958. Elmer Drew Merrill, 1876-1956. In: National Academy of Sciences, National Academy of Sciences Biographical Memoirs. National Academy of Sciences, Washington D.C. Pp. 273-333. 374pp.

Schiebinger, L., 2004. Plants and Empire: Colonial Bioprospecting in the Atlantic World. Harvard University Press, Cambridge. 306pp. 